\title{
FEMALE MIGRATION IN KOLKATA MUNICIPAL CORPORATION: A DEMOGRAPHIC ANALYSIS
}

\author{
Kamalika Basu \\ Assistant Professor, Department of Geography, Dwijendralal College, Krishnagar, Nadia, West Bengal \\ DOI: 10.46609/IJSSER.2021.v06i05.008 URL: https://doi.org/10.46609/IJSSER.2021.v06i05.008
}

\begin{abstract}
ABSTACT
Migration in West Bengal is a historical process that is shaping the demography, culture and economy of the state. Kolkata, the capital of the state has been selected in this paper for discussion as types and factors of migration are truly different in terms of gender division in Kolkata. Male migrants are mostly economic migrant in compare to the females. In and out migration ratios of the females are not only guided by social factors but also by some economic parameters. Marriage is one of the important criteria of female migration. The study attempts to highlight certain demographic characteristics of female migrants of Kolkata along with their pattern and reason of migration with reference to the insights from the census data. The paper mainly deals to recognise the spatial and temporal variation of female migrants of Kolkata and their categorical justification. The work is based on analysis of census data from 1971 to 2011 and also empirical study conducted in 2019.
\end{abstract}

Key words: Demography, spatial temporal variation, economic migrant, categorical justification

\section{Introduction}

Migration is always fascinating issue for the demographers. Elaborate theories have been formulated on the subject and different policy interventions are designed to reduce the effects of migration. Migration and urbanisation are the direct manifestation of the process of economic development in space, particularly in the contemporary phase of globalisation. Rates of international migration are increasing and more than half of the world's population now lives in cities. Migrants make up more than 1 billion population or one seventh of the world's population (UNDESA 2016). Population diversity in the developed countries may be attributed to international migration. Apart from fertility and mortality migration is a dynamic process provides enough data to study the spatial variation and inter regional distribution of population in India. 
International Journal of Social Science and Economic Research

ISSN: $2455-8834$

Volume:06, Issue:05 "May 2021"

Migration is an intrinsic part of development and the focus has shifted to female migration, commonly known as feminisation of migration. Female migrants are the most obvious evident of socially guided migration. Although the situation has changed a lot, women still somehow lack a voice in decision making, especially in economic, civil and political fields. The marginalisation of women's concern in the context of migration is related to overall socio-economic status of women, the non-recognition and undervaluation of their work. Large scale female migration is linked to marriage and reasons have curtailed economic significance being attached to the gender dimension of labour migrants.

\section{Review of literature}

Since the present work deals with the status of women migrants, works of women migrants in developed and developing countries have been reviewed.

Boyel et al. (2009) found that family migration has a negative impact on women's employment status. Using data from British Household Panel Survey they considered two neglected issues. Firstly, instead of depending on distances moved to distinguish employment related migrations, they used the information on the reasons for moving on gender basis. Secondly, they considered selection effects and the role of state dependence in relation to women's employment status.

Gopalan (2001), report on the status of women in India found marginalisation of women society, exploitation in the economy, denial access to power, exclusion from decision making and brutalising within and outside the household. The report is dived into 12 chapters covering women's health, educational development, roles, right and opportunities of economic participation, women and environment, law and political status, mass media and welfare development.

Ganguly- Scrase (2003) focuses on globalisation in West Bengal, apparent paradox between women's positive perception on empowerment and overall negative impact on structural adjustment of policies on women.

Bhadra Ray (2014), examined the status of women migrants from Bangladesh to West Bengal and Orissa, their socio-economic condition, pattern of establishment, decision and role in the family.

Mukherjee (2001) observed that the migrants are attracted to the largest metropolises. In migration of landless agricultural labourers are occurring from very backward states in India, in migration rate is high in those districts where general literacy rate is high and investment to agriculture is more. 


\section{International Journal of Social Science and Economic Research}

ISSN: $2455-8834$

Volume:06, Issue:05 "May 2021"

Jafar, K. (2018) examines the role of education as one of the human development indicators, on the role of women migration in Kerala. The dynamics of education and the impact of regional diversity and their effect on female migration ratio of Kerala have been studied in details.

\section{Objectives}

West Bengal has experienced male out migration than female particularly in certain areas. Female migration in Kolkata is highly guided up by social factors. Males are mostly the economic migrants than females. In migration ratio of females is higher in urban Kolkata. Particularly establishment of colonies in Kolkata, since the time of partition of Bengal exhibits a typical social morphology in case of female migrants. Therefore, some specific objectives of this paper to understand the various aspects of female migration in Kolkata are summarized below:

1. To study the trend and pattern of female migration in West Bengal as well as in Kolkata

2. To analyse the reasons behind female migration.

3. To interpret their demographic profile.

4. To illustrate the socio- economic status of the female migrants.

5. Finally, to discuss about their categorical justification.

\section{Data and methodology}

Census data is the main source of information. The present study is based on secondary data collected from the migration tables of census reports from 1971 to 2011. The limitation of this study is there should have been some change in secondary data between 2011 and 2019, so a small primary survey has been conducted to get the present generalised picture of female migrants in Kolkata. 8 wards have been selected randomly covering north, south, west and central east parts of Kolkata municipal corporation area. $0.1 \%$ of female population of each of these wards have been selected by purposive sampling to generate the data. Total 149 numbers of female migrants have been surveyed through structured questionnaires and henceforth, cartographic techniques and quantitative methods are used for analysis and interpretation. Mapping has been done by using GIs software.

Study area for primary survey: In this paper female migrants of Kolkata are the main focus. 8 wards have been selected randomly for field study. Ward no 1 (Cossipur Area) and ward no 4 (Paikpara Area) for northern part of Kolkata, ward no 33( Phoolbagan Area) and 34 (Beleghata Area) for central east part, ward no 75 (Khhiddirpore Area) and ward no 135 
International Journal of Social Science and Economic Research

ISSN: 2455-8834

Volume:06, Issue:05 "May 2021"

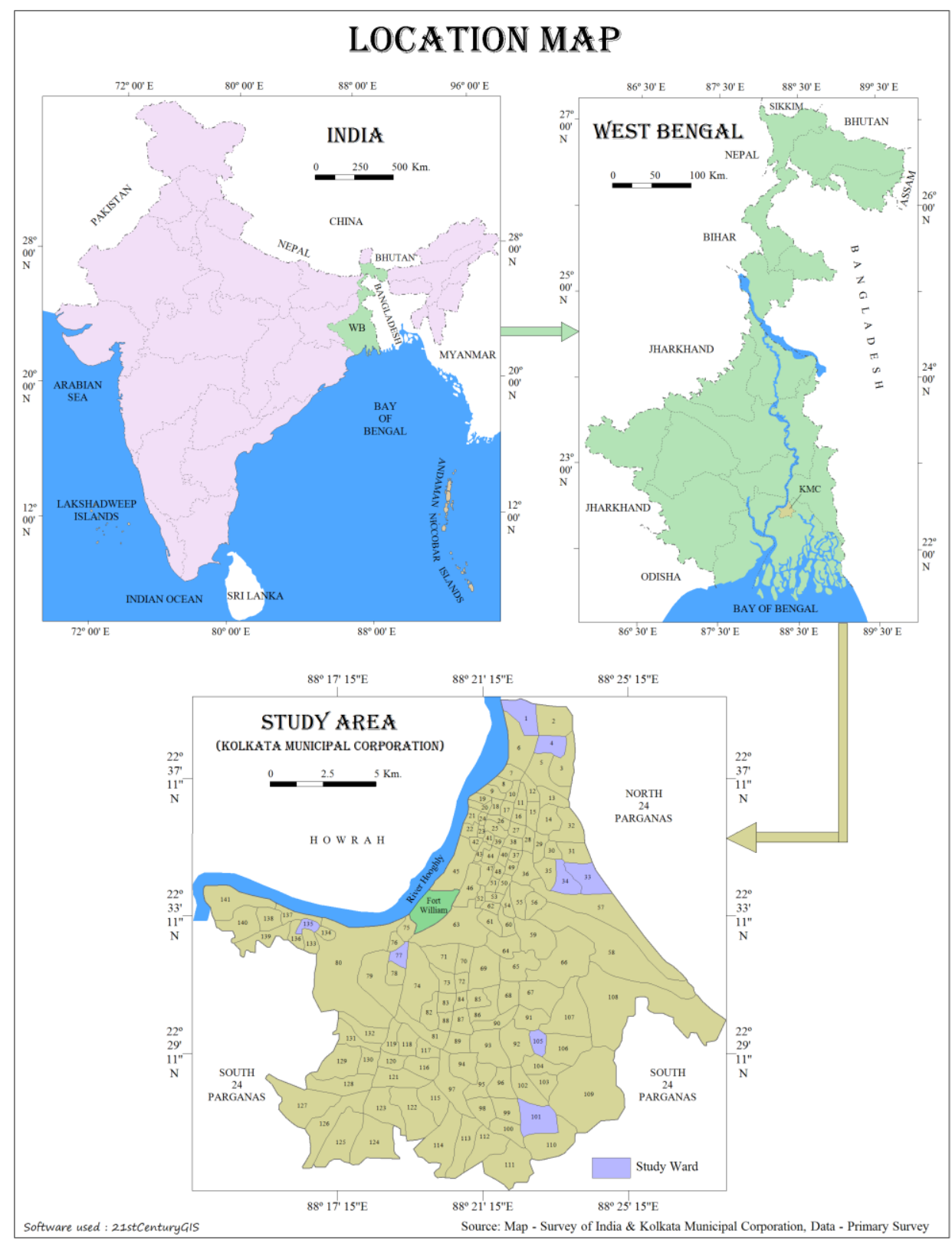

(Gardenreach Area) for western and ward no 101 (Baghajatin Area), and 105( Garfa, Jadavpur Area) for southern part of Kolkata, are the places of sample survey.

\section{Results and discussion}

- Female migrants of Kolkata owe their origin mostly to Bangladesh because partition has its great effect on migration in West Bengal. Rural- Urban and male female distribution of migrants is featured below. 
International Journal of Social Science and Economic Research

ISSN: $2455-8834$

Volume:06, Issue:05 "May 2021"

Table- 1: Rural - Urban and Male - Female Migration from Bangladesh to West Bengal

\begin{tabular}{|c|c|c|c|c|}
\hline YEAR & 1971 & 1981 & 1991 & 2001 \\
\hline Total & 2905065 & 501594 & 477606 & 246446 \\
\hline Male (\%) & 53.82 & 49.55 & 49.77 & 47.47 \\
\hline Female (\%) & 46.18 & 50.45 & 50.23 & 52.53 \\
\hline Rural: Total \& (\%) & 1690580 & 276699 & 300662 & 159210 \\
& $(58.19)$ & $(55.17)$ & $(62.95)$ & $(64.61)$ \\
\hline Male (\%) & 52.79 & 49.64 & 49.56 & 47.56 \\
\hline Female (\%) & 47.21 & 50.36 & 50.44 & 52.44 \\
\hline Urban: Total \& (\%) & 1214485 & 224896 & 176944 & 87236 \\
& $(41.81)$ & $(44.83)$ & $(37.05)$ & $(35.39)$ \\
\hline Male (\%) & 55.24 & 49.45 & 50.12 & 47.31 \\
\hline Female (\%) & 44.76 & 50.55 & 49.88 & 52.69 \\
\hline
\end{tabular}

Source: Census of India 1971,1981,1991,2001 Migration table No-Part-IID (i), Part-V(A \& B), Table D2 1971 is a land mark in the migration volume in West Bengal. Only Bangladesh contributed nearly 3000000 populations to West Bengal.

- The rising share of female migration from Bangladesh to West Bengal has repercussions on the sex ratio of the migrants.

Table- 2: Sex Ratio of Migrants from Bangladesh to West Bengal

\begin{tabular}{|c|c|c|c|c|c|}
\hline Year & 1971 & 1981 & 1991 & 2001 & 2011 \\
\hline Total & 858 & 1018 & 1009 & 1107 & 946 \\
\hline Rural & 894 & 1014 & 1018 & 1103 & 945 \\
\hline Urban & 810 & 1022 & 995 & 1113 & 947 \\
\hline
\end{tabular}

Source: Census of India 1971,1981,1991,2001, 2011 Migration table No-Part-IID(i), Part-V (A \& B), Table D2

N.B.: Sex ratios for 1981 onwards are for $0-9$ years 
International Journal of Social Science and Economic Research

ISSN: 2455-8834

Volume:06, Issue:05 "May 2021"

Table 3: Migration Scenario of West Bengal, 2011 Census

\begin{tabular}{|c|c|c|c|c|c|c|c|}
\hline \multicolumn{4}{|c|}{ Total migrant details of West Bengal } & \multicolumn{4}{|c|}{$\begin{array}{l}\text { Migrant details from Bangladesh to West } \\
\qquad \text { Bengal }\end{array}$} \\
\hline \multirow{2}{*}{$\begin{array}{c}\text { Total } \\
\text { Migrants }\end{array}$} & \multirow[t]{2}{*}{$91,276,115$} & Male & $46,809,027$ & \multirow{2}{*}{$\begin{array}{c}\text { Total } \\
\text { Migrants }\end{array}$} & \multirow[t]{2}{*}{$2,222,091$} & Male & $1,141,821$ \\
\hline & & Female & $44,467,088$ & & & Female & $1,080,270$ \\
\hline \multirow[t]{2}{*}{ Rural } & \multirow[t]{2}{*}{$62,183,113$} & Male & $31,844,945$ & \multirow[t]{2}{*}{ Rural } & \multirow[t]{2}{*}{944,991} & Male & 485,902 \\
\hline & & Female & $30,338,168$ & & & Female & 459,089 \\
\hline \multirow[t]{2}{*}{ Urban } & \multirow[t]{2}{*}{$29,093,002$} & Male & $14,964,082$ & \multirow[t]{2}{*}{ Urban } & \multirow[t]{2}{*}{$1,277,100$} & Male & 655,919 \\
\hline & & Female & $14,128,920$ & & & Female & 621,181 \\
\hline
\end{tabular}

Source: Census of India, 2011, Table no: D1, D1-51 column

- Proportion of female migrant in West Bengal is higher in the rural areas $(68.23 \%)$, but movement of Bangladeshi females (57.5\%) tends to cluster in the urban areas of West Bengal.

- Reasons for female migration to West Bengal from "countries in Asia beyond India", are mostly observed are economic, education, family movement, marriage and some other micro factors. Family movement is found to be the most vital cause among all.

Table 4: Reasons for female migration to West Bengal from Countries of Asia beyond India, 1981 - 2001

\begin{tabular}{|c|c|c|c|c|c|c|c|c|}
\hline \multirow{2}{*}{$\begin{array}{l}\text { Time } \\
\text { Period }\end{array}$} & \multirow{2}{*}{$\begin{array}{c}\text { Total } \\
\text { migrant }\end{array}$} & \multirow{2}{*}{$\begin{array}{c}\text { Total } \\
\text { female } \\
\text { Migrants }\end{array}$} & \multirow{2}{*}{$\begin{array}{c}\% \text { of } \\
\text { Female } \\
\text { Migrants }\end{array}$} & \multicolumn{5}{|c|}{ Reasons of Migration (in \%) } \\
\hline & & & & Economic & Education & $\begin{array}{l}\text { Family } \\
\text { movement }\end{array}$ & Marriage & Others \\
\hline $1971-1981$ & 520213 & 261272 & 50.22 & 2.05 & 0.65 & 41.86 & 18.25 & 37.16 \\
\hline 1981-1991 & 493034 & 247663 & 50.23 & 2.52 & 0.41 & 37.79 & 22.31 & 36.95 \\
\hline $1991-2001$ & 258275 & 135902 & 52.61 & 2.87 & 0.42 & 50.68 & 24.97 & 20.98 \\
\hline
\end{tabular}

Source: Census of India 1981, Migration Table column 23. Part-V (A \& B), 1991 Table D3, 2001 Table D3 (Data are for 0-9 years) 
- Distribution of migrants from Bangladesh to whole West Bengal exhibits the fact the that North 24 Parganas experienced a bulk of migrant population as a consequence urbanisation rate in North 24 Parganas is highest in compare to the other districts of West Bengal, followed by Nadia.

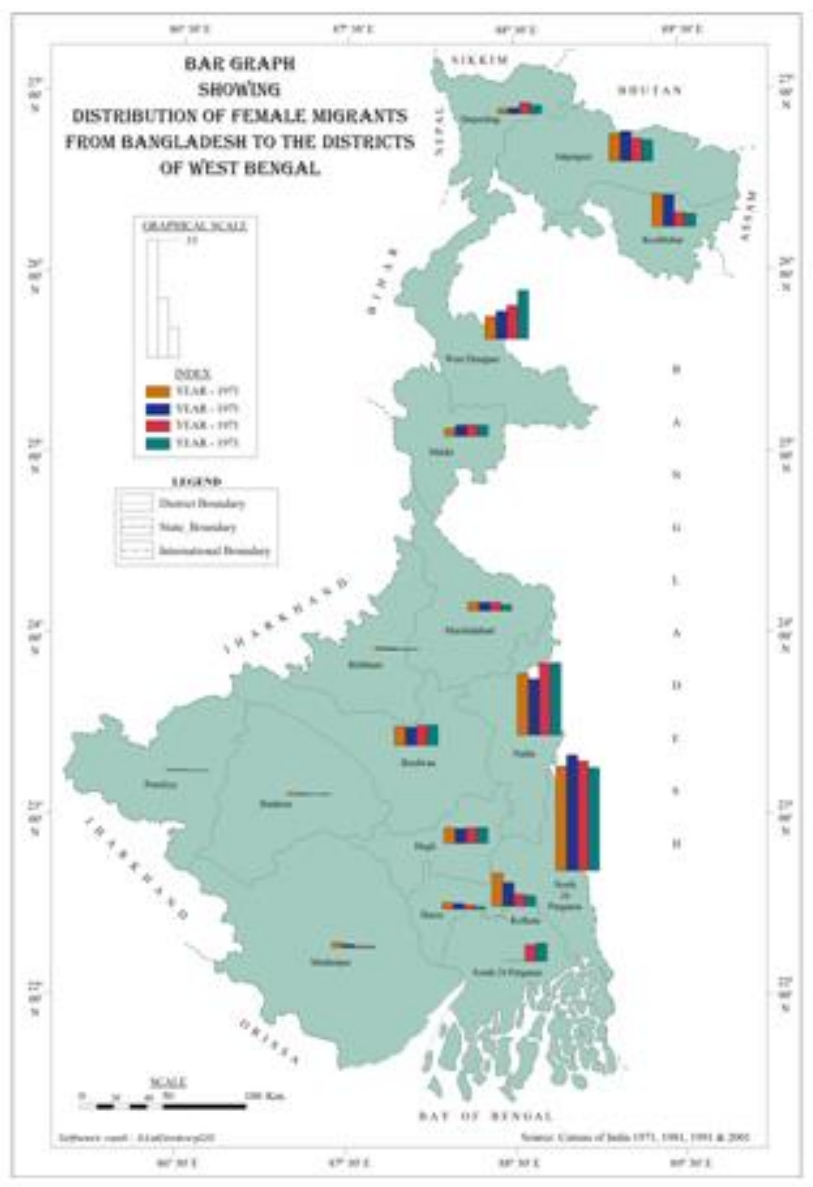

N.B: Data for undivided 24 Parganas for 1971 and 1981 have been shown in 24 Parganas North. Later data for North and South 24 Parganas have been shown separately in the table for 1991 and 2001. Data available for 1991 and 2001 are actually migrants in the age groups of (0-9 years)

Table 5: Reason for Migration in West Bengal from Other States and Countries According to 2011 Census Reports

\begin{tabular}{|c|c|c|c|c|}
\hline \multirow{2}{*}{ Reasons } & Total Migrants & Sex & Total & Percentage \\
\cline { 2 - 5 } & $33,448,472$ & Male & $10,240,751$ & $30.62 \%$ \\
\cline { 3 - 5 } & & Female & $23,207,721$ & $69.38 \%$ \\
\hline
\end{tabular}


International Journal of Social Science and Economic Research

ISSN: 2455-8834

Volume:06, Issue:05 "May 2021"

\begin{tabular}{|c|c|c|c|c|}
\hline \multirow{2}{*}{ Economic } & $2,017,505$ & Male & $1,735,184$ & $86.01 \%$ \\
\cline { 3 - 5 } & & Female & 282,321 & $19.99 \%$ \\
\hline \multirow{2}{*}{ Education } & 164,084 & Male & 113,099 & $86.93 \%$ \\
\cline { 3 - 5 } & & Female & 50,985 & $13.07 \%$ \\
\hline \multirow{2}{*}{ Family Issues } & \multirow{2}{*}{$6,878,196$} & Male & $3,697,111$ & $53.75 \%$ \\
\cline { 3 - 5 } & & Female & $3,181,085$ & $46.25 \%$ \\
\hline Marriage & $16,562,756$ & Male & 342,940 & $2.07 \%$ \\
\cline { 3 - 5 } & & Female & $16,219,816$ & $97.93 \%$ \\
\hline Others & \multirow{2}{*}{$7,825,931$} & Male & $4,352,417$ & $55.62 \%$ \\
\cline { 3 - 5 } & & Female & $3,473,514$ & $44.38 \%$ \\
\hline
\end{tabular}

Source: D1, D2 Table, Census of India, 2011

- The above census table (2011) clearly portrays the fact that the main migrants in West Bengal are the female migrants and the vital cause of their movement is related to the most obvious social cause that is marriage. Other than marriage economic reasons are also important in case the female migrants in West Bengal.

Table 5. Migrants to Kolkata during 1971- 2011

\begin{tabular}{|c|c|c|c|}
\hline Year & $\begin{array}{c}\text { Total population } \\
\text { (Lakhs) }\end{array}$ & $\begin{array}{c}\text { Migrant } \\
\text { population } \\
\text { (Lakhs) }\end{array}$ & \% of Migrants \\
\hline 1971 & 31.5 & 10.62 & 33.86 \\
\hline 1981 & 33.05 & 9.28 & 28.08 \\
\hline 1991 & 43.99 & 7.12 & 21.06 \\
\hline 2001 & 45.73 & 8.22 & 17.98 \\
\hline 2011 & 44.97 & 8.37 & 18.61 \\
\hline
\end{tabular}

Source: Census of India (1951-2011)

- The volume of migration makes no remarkable difference in between 2001 and 2011 ( $0.63 \%$ migrant population have increased). 
International Journal of Social Science and Economic Research

ISSN: $2455-8834$

Volume:06, Issue:05 "May 2021"

Table 6: Share of Female Migrants in Kolkata (2011)

\begin{tabular}{|c|c|c|c|c|}
\hline $\begin{array}{c}\text { Total } \\
\text { Migrants }\end{array}$ & Male & $\begin{array}{c}\text { \% of male } \\
\text { migrants }\end{array}$ & $\begin{array}{c}\text { Female of female } \\
\text { migrants }\end{array}$ \\
\hline 837,138 & 440,103 & 52.57 & 397,035 & 47.43 \\
\hline
\end{tabular}

Source: Census of India, 2011 (Table D1)

\section{Sample Survey Analysis on Kolkata Municipal Corporation Area (2019):}

- Surveyed female migrants mostly lie under the age group of 25-50, who shared their experience and cause of migration. Family movement and marriage are the two major reasons behind their migration.

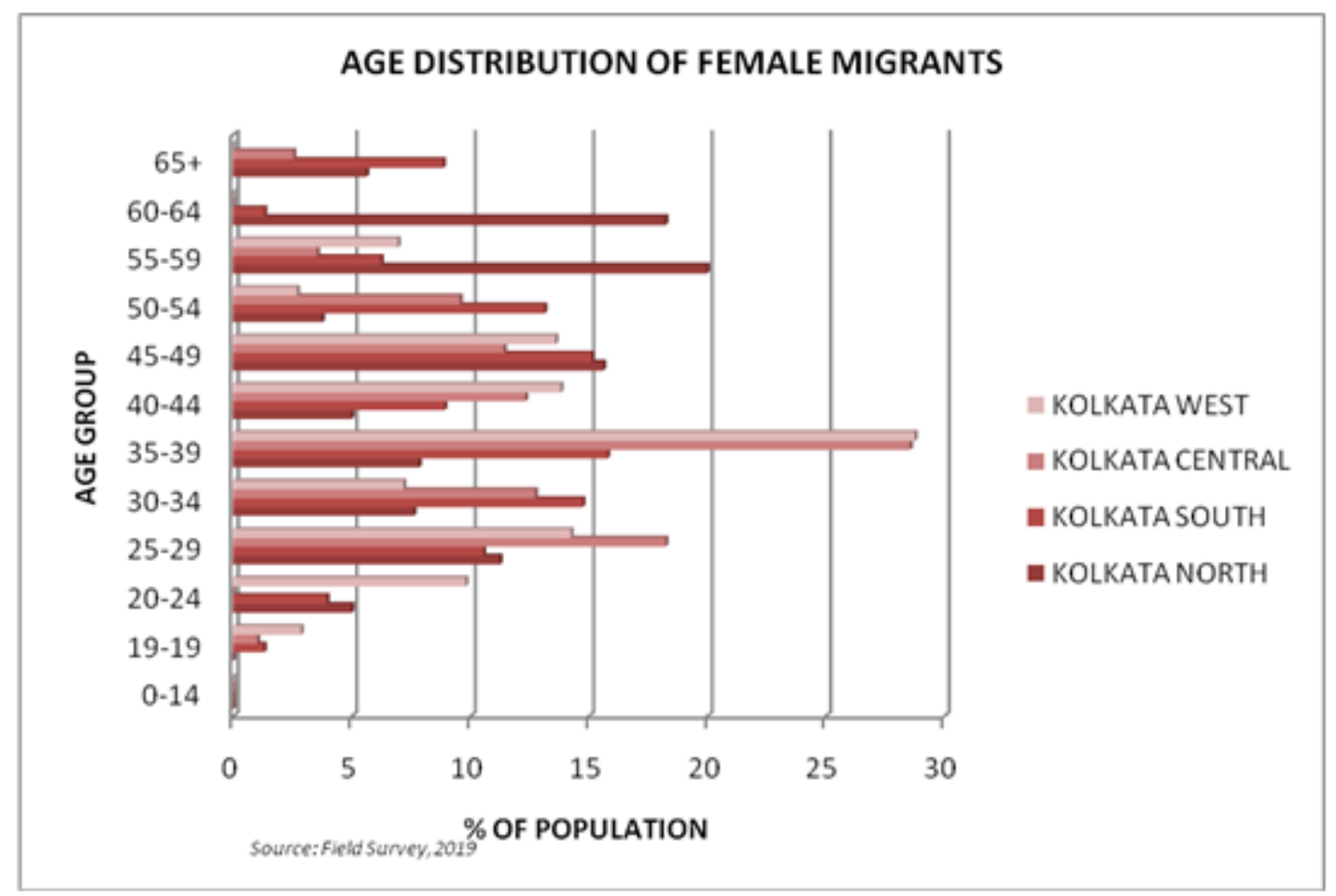

- Caste distribution of the surveyed population portrays that $\mathrm{OBC}$ concentration among the female migrants is higher in Kolkata north and west. Pertinently it is important to mention that most of these $\mathrm{OBC}$ female migrant belong to Muslim community. 
International Journal of Social Science and Economic Research

ISSN: 2455-8834

Volume:06, Issue:05 "May 2021"

Table - 4 : Caste Distribution of Female Migrants in Kolkata

\begin{tabular}{|c|c|c|c|c|}
\hline Caste & Kolkata North & Kolkata South & Kolkata Central & Kolkata West \\
\hline SC & 9.13 & 47.25 & 32.2 & 10.8 \\
\hline ST & 0 & 0 & 2.07 & 0 \\
\hline OBC & 65.64 & 6.87 & 12.42 & 53.0 \\
\hline GEN & 25.23 & 45.88 & 53.31 & 36.2 \\
\hline
\end{tabular}

Source: Field Survey, 2019

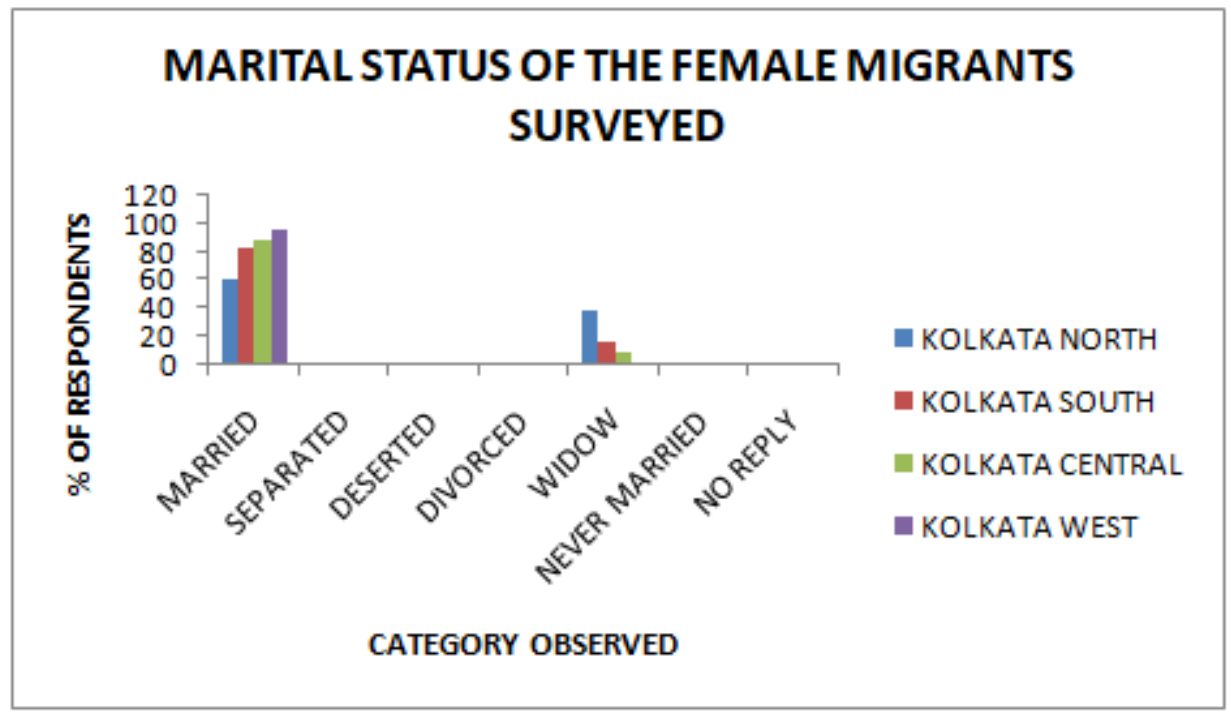

- Regarding the marital condition of these females, most of them are married; rather marriage is the main cause of their migration.

- Economic condition of these females is summarized by categorising them on the basis of their professional attachment. During the survey some of the slum population and colony area of Kolkata were covered that reveals most of these females are working as daily labours mainly in household activities or as maid servants. Some of them are occupied in market enterprises, like fruits and vegetables selling etc. The Muslim migrants are typically found to be engaged in a distinctive function that is tailoring, "Embroidery and Zari" working. This work is mostly performed from home or from nearby locality. The rest are actually involved in various official jobs. Income slab exhibits their financial condition very well. 
- Talking about the origin and nature of female migration, Bangladesh contributed a lot of female migrant to whole West Bengal and step migration was predominant in Kolkata. Partition in Bengal resulted to a huge bulk of female migrants in North 24 Parganas, Nadia and Murshidabad. Later from these areas women have come to Kolkata mainly for economy and few for education. A huge volume of migrants in the socially excluded parts of the city have concentrated directly due to forced migration, family movement and marital reasons. North Kolkata proves this fact. In the last ten years south Kolkata was over populated due to concentration of female migrants from south 24 Parganas. The in migration ratio of south Kolkata is higher in recent years than north Kolkata.

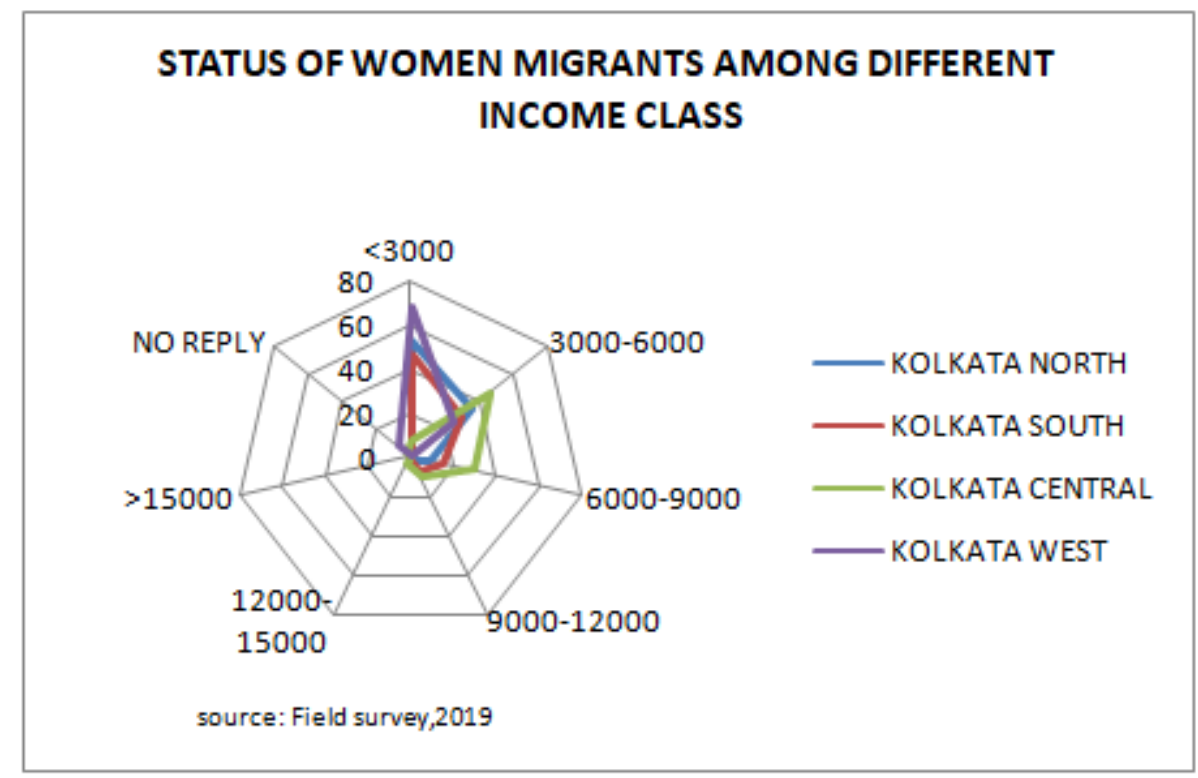

Table - 5: Distribution of \% of Female Migrants on the basis of origin

\begin{tabular}{|c|c|c|c|c|}
\hline Origin & Kol_North & Kol_South & Kol_Central & Kol_West \\
\hline Bangladesh & 33.06 & 21.11 & 51.51 & 4.86 \\
\hline $\begin{array}{c}\text { North 24 } \\
\text { Parganas }\end{array}$ & 35.96 & 3.61 & 23.24 & 2.57 \\
\hline $\begin{array}{c}\text { South 24 } \\
\text { Parganas }\end{array}$ & 2.85 & 43.24 & 13.25 & 0 \\
\hline Murshidabad & 13.85 & 17.01 & 0 & 15.26 \\
\hline Nadia & 3.20 & 2.85 & 0 & 3.77 \\
\hline
\end{tabular}


International Journal of Social Science and Economic Research

ISSN: 2455-8834

Volume:06, Issue:05 "May 2021"

\begin{tabular}{|c|c|c|c|c|}
\hline Bankura & 0 & 2.60 & 0 & 0 \\
\hline Birbhum & 0 & 4.37 & 0 & 0 \\
\hline West Medinipur & 1.21 & 0 & 0 & 0 \\
\hline East Medinipur & 0 & 0 & 2.56 & 3.52 \\
\hline Haora & 2.52 & 5.21 & 3.33 & 23.51 \\
\hline Hugli & 0 & 0 & 3.85 & 0 \\
\hline Bardhaman & 1.21 & 0 & 0 & 0 \\
\hline Uttar Pradesh & 2.65 & 0 & 0 & 19.27 \\
\hline Bihar & 3.49 & 0 & 2.25 & 21.3 \\
\hline Gujarat & 0 & 0 & 0 & 5.94 \\
\hline
\end{tabular}

Source: Primary Survey, 2019

In compare to northern and southern parts, Western part of Kolkata is found to be affected mainly by interstate migration. Female Migrants of Khiddirpore and Gardenreach area are mostly Hindi speaking and their origin owes to Uttar Pradesh and Bihar. A few of them have been sheltered due to political unrest in Western India. These female migrants are not economic migrant. In recent years the migration patterns of the women have changed in Kolkata. Education and occupational diversity have acted as pull factors for the female migrants. These have resulted to step migration in Kolkata. Migration pattern observed in Kolkata are generalised on the basis of sample survey conducted in some of the wards of Kolkata. 
International Journal of Social Science and Economic Research

ISSN: 2455-8834

Volume:06, Issue:05 "May 2021"

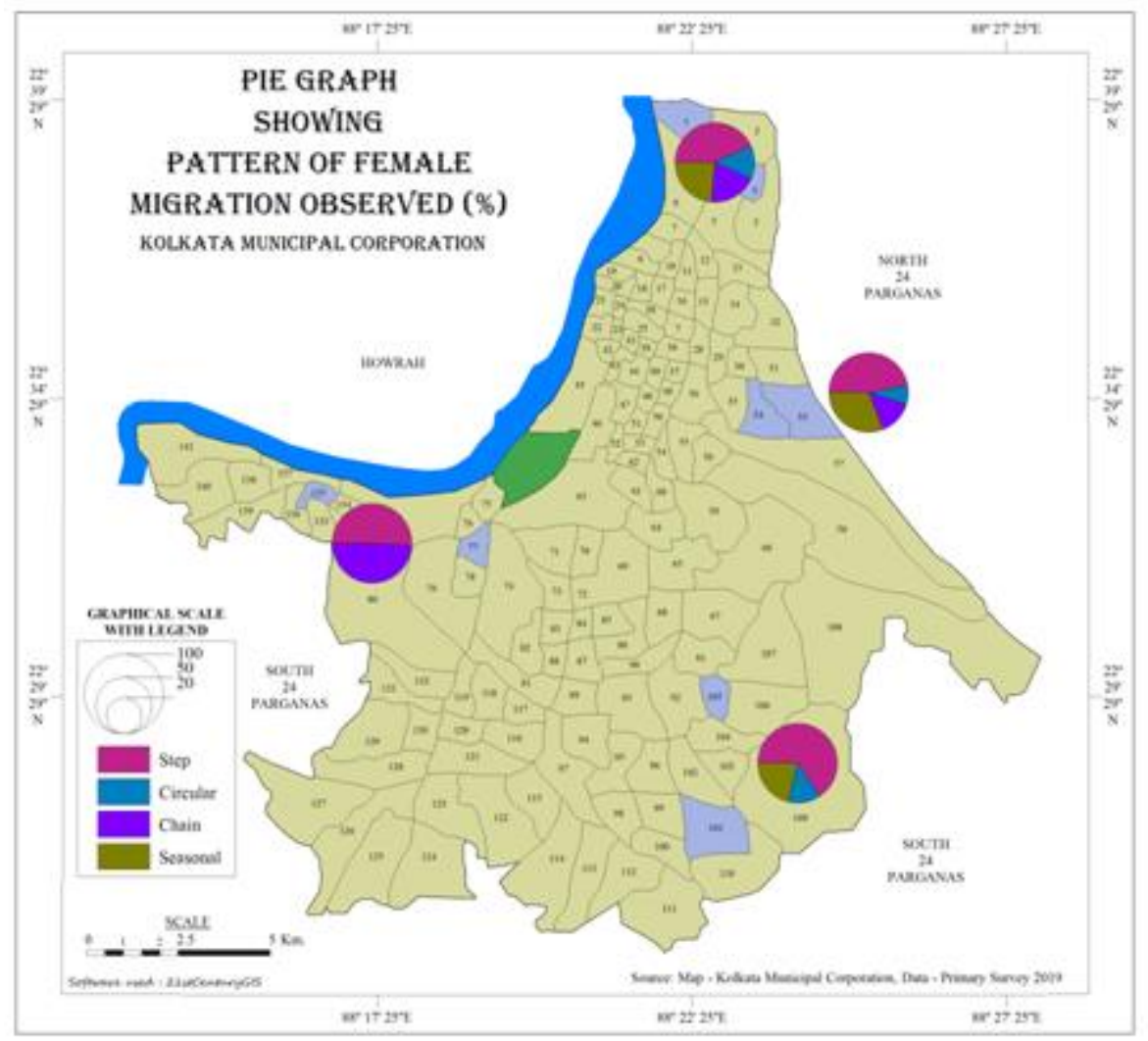

\section{Summary of major findings}

1. Effects of international migration that was observed since the time of partition resulted a huge disparity in the "in and out migration ratio" of the female migrants in Kolkata.

2. Men are mostly economic migrant in Kolkata than females. In recent years though the ratio has changed but disparity is still observed.

3. Education and economy are the secondary cause of female migration in Kolkata. Specially the slums and colony settlement proves that marriage and family movement are the major reasons of migration.

4. The oral interviews have revealed the fact that the most of the female migrants are actually asylee in nature; they have been approved by the Government to stay in Kolkata with voter right. The migrants who have their origin to Bangladesh are IDP, but that is true in case of their ancestors who were forced to migrate in West Bengal in that time. Some of the Muslim migrants of west Kolkata are also sheltered and authorised by Government during political disturbances in Western India. 


\section{International Journal of Social Science and Economic Research}

ISSN: $2455-8834$

Volume:06, Issue:05 "May 2021"

5. Step migration is the most observed pattern of female migration in Kolkata. These migrants contribute in economic activities and henceforth can be termed as economic migrants too.

6. In recent years the female migrants of lower income group are trying to engage themselves to economic activities of various types.

\section{Conclusion}

Migration is a continuous process that is influenced both by development and under development. Study of female migration in Kolkata as well as in India requires much more exploration for the better understanding of their problems. In spite of Government policies and different laws of migration there lies a large gap between the theoretical and practical situation. Kolkata, a fast-growing metro city in India, should experience a true modernisation and women empowerment in case of female migrants.

\section{References}

1. Thadani Veena \& Todaro Michael, 1984, "Female Migration: A Conceptual Framework, Fawcett et al.

2. United Nation 1991, "International Migration of Women in Developing Countries

3. Mamsen J. Henshall (ed) 1991, “Gender, Migration and Domestic Service”, Routledge, London

4. Sahoo H, Ram F, 2017, Population Issues, Rawat Publication

5. Keshari, K., Bhagat, R.B.,2012, “Temporary and Seasonal Migration: Regional Pattern, Characteristics and Associated Factors", Economic \& Political Weekly, Vol 47(4),81-88

6. Census of India, 1971, 1981, 1991 \& 2001, Migration Tables, Registrar General and Census Commissioner of India, Government of India, New Delhi.

7. Shanthi, K.,2006, "Female Labour Migration in India.: Insights from The Census Data

8. West Bengal Human Development Report, 2004, Development and Planning Department, Government of West Bengal

9. Jordon B., Duvell F, 2015, "Migration”, Rawat Publication 
10. Mukherji, Shekhar, 2001, "Low Quality Of Migration In India: The Phenomena on Distressed, Migration", Published in "Poverty Induced Migration And Urban Involution In ESCAP Region", Required Planning Strategies, Research Report No 26-2000 IIPS, Mumbai.

11. Kundu, A, Sarangi, N, 2007, "Migration, Employment Status and Poverty: An Analysis Across Urban Centres," Economic and Political Weekly, January, 299-306

12. Dholakia, J. R. ,2008, "Basic Concept of Migration and Urbanisation", Published In "Urbanisation: Issues and Perspectives, The ICFAI University Press, Hydrabad, 1-15

13. Kumar, B.B., 2006, "Illegal Migration from Bangladesh", Astha Bharati, Delhi. 